\title{
Biological catalyzed denitrification by a functional electropolymerization biocarrier modified by redox mediator
}

\author{
Huijuan Liu ${ }^{\mathrm{a}}$, Jianbo Guo ${ }^{\mathrm{a}, \mathrm{b}}$, Jiuhui Qu ${ }^{\mathrm{a}, *}$, Jing Lian ${ }^{\mathrm{b}}$, Yankai Guo ${ }^{\mathrm{b}}$, William Jefferson ${ }^{\mathrm{a}}$, Jingliang Yang ${ }^{\mathrm{b}}$ \\ a State Key Laboratory of Environmental Aquatic Chemistry, Research Center for Eco-Environmental Sciences, Chinese Academy of Sciences, Beijing 100085, PR China \\ ${ }^{\mathrm{b}}$ School of Environmental Science and Engineering, Hebei University of Science and Technology, Yuhua East Road 70\#, Shijiazhuang City 050018, PR China
}

\section{A R T I C L E I N F O}

\section{Article history:}

Received 11 October 2011

Received in revised form 12 December 2011

Accepted 13 December 2011

Available online 22 December 2011

\section{Keywords:}

Functional electropolymerization biocarrier

Redox mediator

Anthraquinone-2-sulfonate (AQS)

Denitrification

\begin{abstract}
A B S T R A C T
Electropolymerization biocarriers were prepared by the electropolymerization of polypyrrole (PPy) on an active carbon felt (ACF) electrode using doping anions anthraquinone-2-sulfonate (AQS) or $\mathrm{Na}_{2} \mathrm{SO}_{4}$. The functional electropolymerization biocarrier (ACF/PPy/AQS) with AQS was used as an immobilized redox mediator for the denitrification process. The characteristics of the electropolymerization biocarriers were analyzed by scanning electron microscope, elemental analyses, Fourier transform infrared (FTIR) spectroscopy and Raman spectroscopy. The results suggested that the denitrification efficiency increased nearly 1.5 -fold with $\mathrm{ACF} / \mathrm{PPy} / \mathrm{AQS}\left(0.04 \mathrm{mmol} \mathrm{L}^{-1} \mathrm{AQS}\right)$ compared to the control. A linear correlation was found for the $k$ value and the AQS concentration $\left(C_{\mathrm{AQS}}\right)$, which was $k=624.71 C_{\mathrm{AQS}}+83.87$ $\left(R^{2}=0.9893\right)$. The ORP value stabilized around $-200 \mathrm{mV}$ for the denitrification process with $\mathrm{ACF} / \mathrm{PPy} /$ $\mathrm{AQS}$, which was $-25 \mathrm{mV}$ lower than that with $\mathrm{ACF} / \mathrm{PPy} / \mathrm{Na}_{2} \mathrm{SO}_{4}$. Repeated-batch operations indicated that the denitrification efficiency with ACF/PPy/AQS maintained over $90 \%$ of the original value and exhibited better catalytic activity and durability.
\end{abstract}

(c) 2011 Elsevier Ltd. All rights reserved.

\section{Introduction}

Discharged nitrogen-containing compounds can create serious environmental problems such as the eutrophication of rivers and lakes, deterioration of water quality and potential hazards to human or animal health (Wang et al., 2009; Yang et al., 2011). With increasing nitrate pollution and strict limits set by legislation, higher nitrogen removal efficiency has become an interesting topic in wastewater treatment. In recent years, many new biological technologies, such as anaerobic ammonium oxidation (ANAMMOX) (Jetten et al., 2001; Suneethi and Joseph, 2011) and oxygen-limited autotrophic nitrification-denitrification (OLAND) (Pathak et al., 2007) have been developed based on the new discovery and advancement of microorganism principles. Currently operational cost and low denitrification rate are still limiting factors for the application of these technologies and must be considered in their selection for nitrogen removal processes. Consequently, it is very important to find a novel and economical biological process for nitrogen removal.

During the last two decades, some studies have been conducted to explore the catalytic effects of different redox mediators on the bio-transformation processes of perchlorate, arsenate, nitrate and azo dyes (Van der Zee and Cervantes, 2009; Hong and Gu, 2009).

\footnotetext{
* Corresponding author. Fax: +86 1062849160 .

E-mail address: jhqu@rcees.ac.cn (J. Qu).
}

Redox mediators can reversibly be oxidized and reduced, and have the capacity to serve as electron carriers in multiple redox reactions, and accelerate reactions by lowering the activation energy of the total reaction. The simultaneous conversion of sulfide and nitrate in a denitrifying culture was reported to be enhanced with the addition of some soluble quinoid redox mediators (ArandaTamaura et al., 2005), in which continuous dosing implies continuous consumption of soluble redox mediator as well as continuous discharge of biologically recalcitrant compounds. A novel non-dissolved redox mediator catalyzing biological denitrification (RMBDN) was also explored, and the denitrification rate was enhanced about 1.5 fold with immobilized anthraquinone (Guo et al., 2010). However, the non-dissolved redox mediator was not ideal due to low mechanical strength (Guo et al., 2007, 2010). Therefore, a search for an effective method to immobilize a dissolved redox mediator (such as anthraquinone-2-sulfonate (AQS)) in the bioreactor was needed.

The aim of this study was to explore a new denitrification technology with functional electropolymerization biocarriers, which were prepared by the electropolymerization of polypyrrole (PPy) monomer on an active carbon felt (ACF) electrode with doping anions anthraquinone-2-sulfonate (AQS, redox mediator) or $\mathrm{Na}_{2} \mathrm{SO}_{4}$. The accelerating mechanism of the redox mediator was explained and analyzed for ORP and electron transport. In addition, the biological catalytic activity and durability were also tested by repeated-batch operations. 


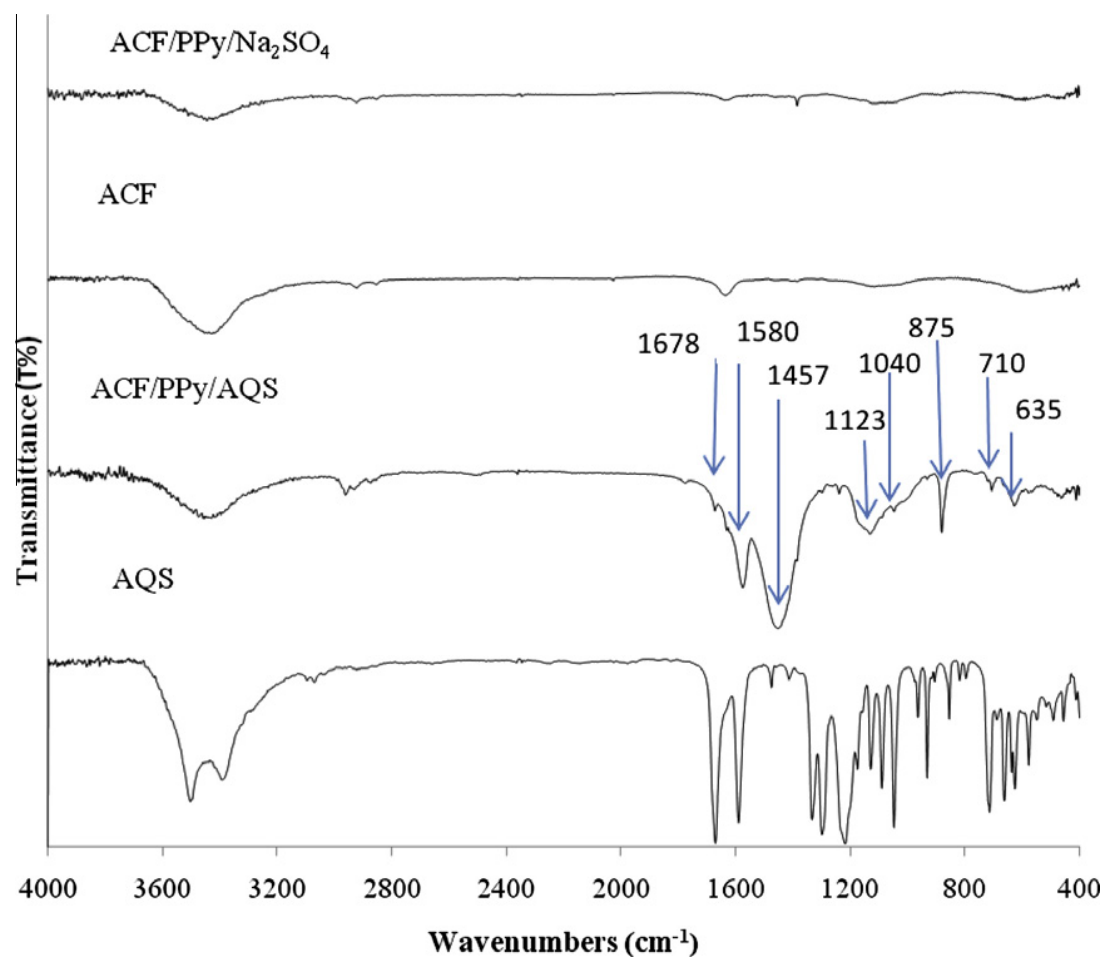

Fig. 1. FTIR spectrum of the different electropolymerization biocarriers.

\section{Methods}

\subsection{Chemicals}

Pyrrole (Py) monomer (Aldrich, 99\%) was distilled twice before use. All solutions were prepared using deionized water. Active carbon felt (ACF) (BET surface of $800 \mathrm{~m}^{2} \mathrm{~g}^{-1}, 4 \mathrm{~mm}$ thick) was purchased from Anshan Senxin Activated Carbon Fiber Plant, China. All other chemical reagents were analytical grade and were purchased from Xiandai Ltd. (Shijiazhuang, China).

\section{2. $A C F / P P y / A Q S$ preparation}

The functional electropolymerization biocarriers of ACF/PPy/ AQS were prepared as follows: In the working electropolymerization compartment, $150 \mathrm{ml}$ of aqueous solution was placed containing $0.1 \mathrm{M}$ Py monomer and $0.024 \mathrm{M} \mathrm{AQS}$ or $0.024 \mathrm{M} \mathrm{Na}_{2} \mathrm{SO}_{4}$. A sheet of ACF represented the working electrode with a platinum plate $(2.5 \mathrm{~cm} \times 2 \mathrm{~cm})$ counter electrode. Then, the functional electropolymerization biocarriers were prepared under cyclic voltammetry mode $(0.55-0.75 \mathrm{~V}, 0.005 \mathrm{~V} / \mathrm{s})$ controlled by a Voltalab Powersuite/LK98B II (Tianjin Lanlike Electronics Technology Ltd., China) for $3 \mathrm{~h}$. ACF/PPy/AQS was then cleaned twice using distilled water and kept in distilled water saturated with high purity $\mathrm{N}_{2}$ gas before use. The AQS concentration was calculated by the sum of added sheets of ACF/PPy/AQS and the redox mediator amount of each sheet. The AQS amount of each sheet of ACF/PPy/AQS was about $0.0025 \mathrm{mmol}$, which was calculated as the change in the added AQS concentration in the electropolymerization solution system.

\subsection{Organism and medium}

Paracoccus versutus strain GW1 (1416 bp, GU111570) was a heterotrophic denitrification bacterium from "The Hebei Key Laboratory of Environmental Biotechnology", and was cultivated in a metal medium (Guo et al., 2010) which consisted of: $1.25 \mathrm{~g} \mathrm{KHCO}_{3}$, $0.025 \mathrm{~g} \mathrm{KH}_{2} \mathrm{PO}_{4}, 0.3 \mathrm{~g} \mathrm{CaCl}_{2} \cdot 2 \mathrm{H}_{2} \mathrm{O}, 0.2 \mathrm{~g} \mathrm{MgSO}_{4} \cdot 7 \mathrm{H}_{2} \mathrm{O}, 0.00625 \mathrm{~g}$ $\mathrm{FeSO}_{4}$, and $0.00625 \mathrm{~g}$ EDTA per liter and $1 \mathrm{ml} \mathrm{L}^{-1}$ of trace elements solution. The trace element solution contained: $15 \mathrm{~g}$ EDTA, $0.43 \mathrm{~g}$ $\mathrm{ZnSO}_{4} \cdot 7 \mathrm{H}_{2} \mathrm{O}, \quad 0.24 \mathrm{~g} \quad \mathrm{CoCl}_{2} \cdot 6 \mathrm{H}_{2} \mathrm{O}, \quad 0.99 \mathrm{~g} \quad \mathrm{MnCl}_{2} \cdot 4 \mathrm{H}_{2} \mathrm{O}, \quad 0.25 \mathrm{~g}$ $\mathrm{CuSO}_{4} \cdot 5 \mathrm{H}_{2} \mathrm{O}, 0.22 \mathrm{~g} \mathrm{NaMoO}_{4} \cdot 2 \mathrm{H}_{2} \mathrm{O}, 0.19 \mathrm{~g} \mathrm{NiCl} 2 \cdot 6 \mathrm{H}_{2} \mathrm{O}, 0.21 \mathrm{~g} \mathrm{Na}-$ $\mathrm{SeO}_{4} \cdot 10 \mathrm{H}_{2} \mathrm{O}, 0.014 \mathrm{~g} \mathrm{H}_{3} \mathrm{BO}_{4}$, and $0.05 \mathrm{~g} \mathrm{NaWO}_{4} \cdot 2 \mathrm{H}_{2} \mathrm{O}$ per liter. $\mathrm{NO}_{3}^{-}$was used in the form of $\mathrm{NaNO}_{3}$.

Strain GW1 was grown for two days at $\mathrm{pH} 7.0-7.5$ and $35^{\circ} \mathrm{C}$ (Data is shown in Supporting information (SI) Fig. S1 and Fig. S2). Carbon sources and $\mathrm{C} / \mathrm{N}$ ratio were sodium acetate and 6 , respectively (Fig. S3). The biomass concentration was determined from the optical density (OD) at $660 \mathrm{~nm}$, and the concentration of strain GW1 was adjusted to $5.7 \mathrm{~g}$ dry cell weight $\mathrm{L}^{-1}$ in all experiments.

\subsection{Batch denitrification experiments}

An adsorption experiment was conducted to estimate the adsorption capacity for nitrate. ACF/PPy/AQS without bacteria was added into $400 \mathrm{mg} \mathrm{NO}_{3}^{-}-\mathrm{N} \mathrm{L}^{-1}$ synthetic wastewater. The residual $\mathrm{NO}_{3}^{-}-\mathrm{N}$ concentration in the synthetic wastewater was detected as a function of time until equilibrium.

Specific amounts of ACF/PPy/AQS were placed in a $250 \mathrm{ml}$ growth medium containing designated nitrate concentrations. Denitrification with an identical amount of $\mathrm{ACF} / \mathrm{PPy} / \mathrm{Na}_{2} \mathrm{SO}_{4}$ was also performed as a control experiment. To evaluate the denitrification efficiency, batch denitrification experiments were conducted under different AQS concentrations $\left(0-0.04 \mathrm{mmol} \mathrm{L}^{-1}\right)$ and different initial $\mathrm{NO}_{3}^{-}-\mathrm{N}$ concentrations (200-700 $\mathrm{mg} \mathrm{L}^{-1}$ ). At the same time, $\mathrm{pH}$ and ORP changes were measured to analyze the AQS role during the denitrification process.

\subsection{Repeated-batch operations}

Repeated-batch operations were conducted to study the reusability of ACF/PPy/AQS in industrial applications. ACF/PPy/AQS 

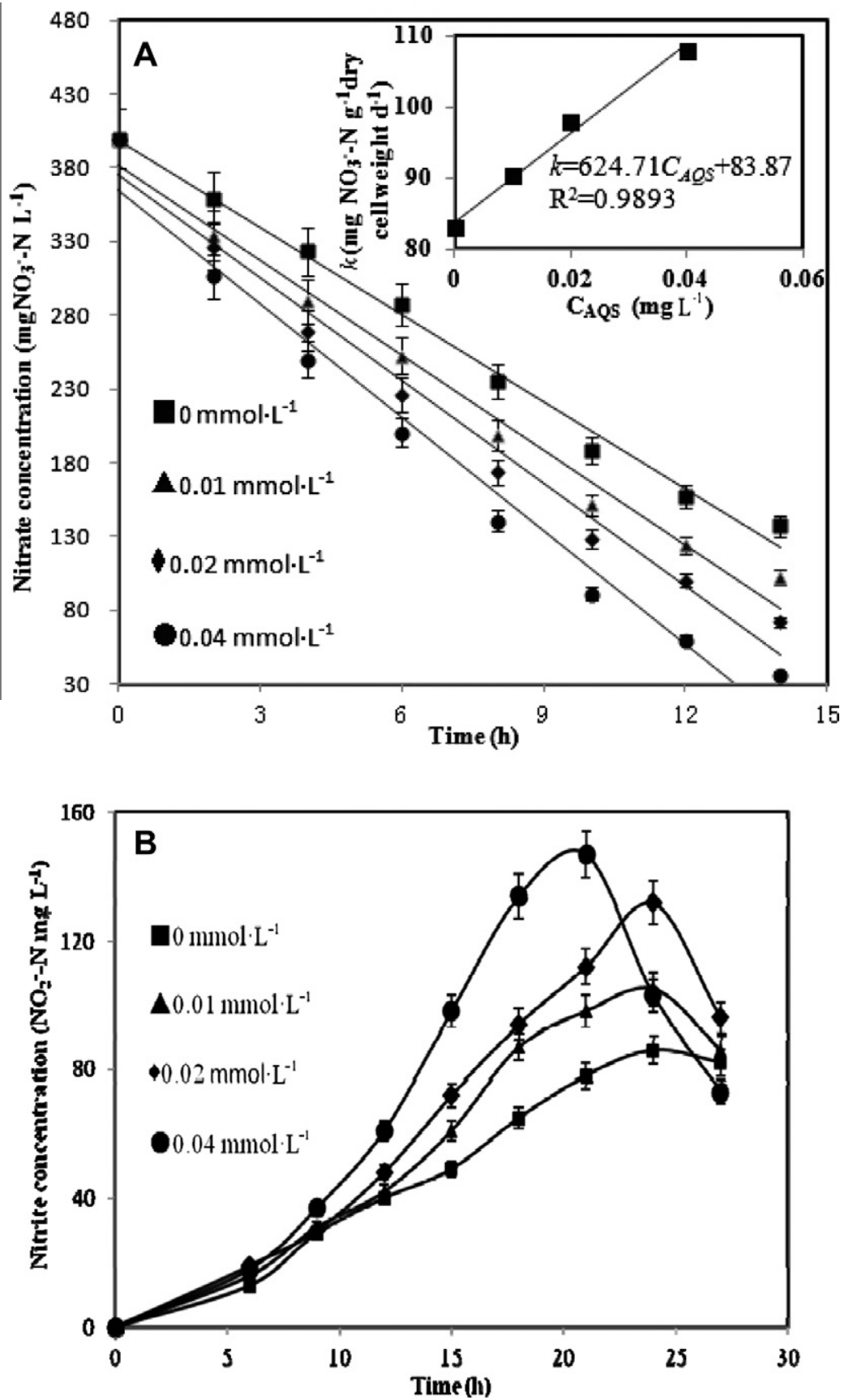

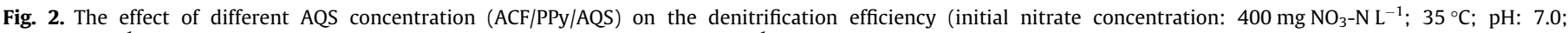
$0.01 \mathrm{mmol} \mathrm{L}{ }^{-1} \mathrm{AQS}$; carbon source: sodium acetate; C/N: 6; $5.7 \mathrm{~g}$ dry cell weight $\mathrm{L}^{-1}$ ).

Table 1

Comparison of documented denitrification rates $\left(\mathrm{g} \mathrm{NO}_{3}-\mathrm{N} \mathrm{g}^{-1} \mathrm{VSS} \mathrm{d}^{-1}\right)$ using different denitrification processes.

\begin{tabular}{|c|c|c|c|c|}
\hline Carbon source & Maximum denitrification rate $\left(\mathrm{g} \mathrm{NO}_{3}-\mathrm{N} \mathrm{g}^{-1} \mathrm{VSS} \mathrm{d}^{-1}\right)$ & Type of wastewater & Input $\mathrm{NO}_{3}-\mathrm{N}\left(\mathrm{mg} \mathrm{L}^{-1}\right)$ & References \\
\hline Sodium acetate & $81.29^{a}$ & Synthetic wastewater & 3388 & Dhamole et al. (2007) \\
\hline Acetic acid & $1.16^{\mathrm{a}}$ & Stainless steel wastewater & 2500 & Fernández-Nava et al. (2010) \\
\hline Sodium acetate & $7.76^{\mathrm{a}}$ & Explosive factory & 3600 & Shen et al. (2009) \\
\hline Acetic acid & $1.2^{\mathrm{a}}$ & Artificial groundwater & $2700-8200$ & Glass and Silverstein (1999) \\
\hline Acetic acid & $45.6^{\mathrm{a}}$ & Synthetic wastewater & $>500$ & Rodriguez et al. (2007) \\
\hline Methanol & 0.486 & Synthetic wastewater & 500 & Bilanovic et al. (1999) \\
\hline Sodium acetate & 108 & Synthetic wastewater & $200-700$ & In this study \\
\hline
\end{tabular}

a Converted from $\mathrm{g} \mathrm{NO}_{3}^{-}-\mathrm{N} \mathrm{g}^{-1} \mathrm{VSS} \mathrm{h}^{-1}$ to $\mathrm{g} \mathrm{NO}_{3}^{-} \mathrm{g}^{-1} \mathrm{VSS} \mathrm{d}^{-1}$. 


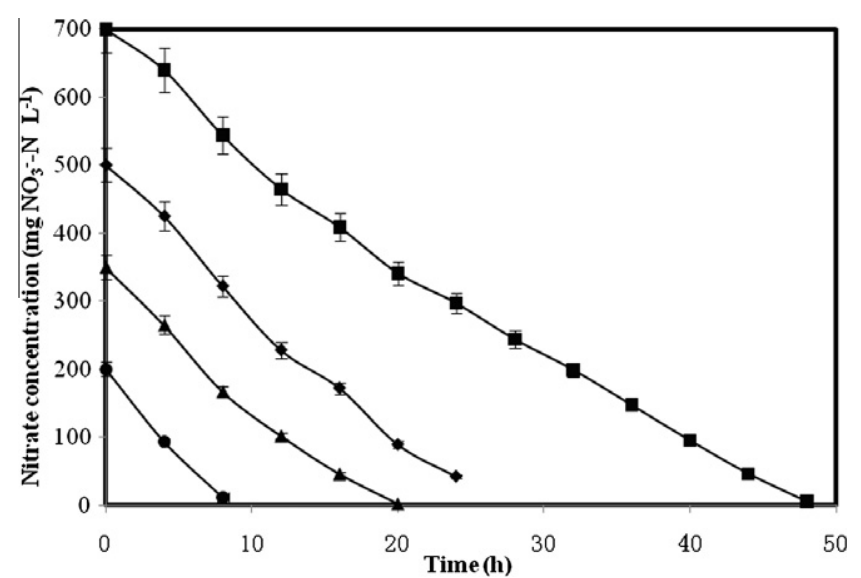

Fig. 3. The effect of different intial nitrate concentration on the denitrification efficiency with $\mathrm{ACF} / \mathrm{PPy} / \mathrm{AQS}\left(0.01 \mathrm{mmol} \mathrm{L}^{-1} \mathrm{AQS} ; 35^{\circ} \mathrm{C}\right.$; $\mathrm{pH}$ : 7.0 ; carbon source: sodium acetate; C/N: 6; $5.7 \mathrm{~g}$ dry cell weight $\left.\mathrm{L}^{-1}\right)$.

was placed into a medium containing $350 \mathrm{mg} \mathrm{L}^{-1} \mathrm{NO}_{3}^{-}$(pH 7.5) and was then statically incubated at $35^{\circ} \mathrm{C}$ for denitrification. After complete denitrification, ACF/PPy/AQS was collected, rinsed twice with sterile deionized water and transferred into a fresh medium containing $350 \mathrm{mg} \mathrm{NO}_{3}^{-}-\mathrm{N} \mathrm{L}^{-1}$ for the next denitrification experiment. The same procedures were repeated four times.

\subsection{Analytical methods}

For the batch denitrification experiment, samples were withdrawn at predetermined times and centrifuged at $8000 \times g$ for $15 \mathrm{~min}$ to remove the insoluble particles. The nitrate concentration in the supernatant was measured colorimetrically using UV spectrophotometry (U-3010, UV/VS spectrophotometer, HITACHI, Co., Japan). The $\mathrm{pH}$ and ORP value change during the denitrification process was measured with a digital $\mathrm{pH}$ Meter (Delta-320, China) and an ORP composite electrode (Leici-501, China), respectively.

Elemental analysis was carried out by an Elementar Vario EL III (Germany) to acquire information about the elemental composition and the doping ratio of electropolymerization biocarrier. Infrared spectroscopy was also performed using $\mathrm{KBr}$-pellets with a Fourier transform infrared spectrometer (FTIR, Nicolet5700, Thermo Electron Corporation, USA) to gain the chemical structure of the electropolymerization biocarrier. Raman spectra were recorded with a visible-light Raman spectrophotometer assembled by Dalian Institute of Chemical Physics, Chinese Academy of Sciences. An S-4800-I scanning electron microscope (SEM, Hitachi, Japan,) was used to observe the morphology of the electropolymerization biocarrier.

All experiments were performed in triplicate.

\section{Results and discussion}

\subsection{Characterization of ACF/PPy/AQS}

The morphology and microstructure of $\mathrm{ACF}, \mathrm{ACF} / \mathrm{PPy} / \mathrm{Na}_{2} \mathrm{SO}_{4}$, fresh $\mathrm{ACF} / \mathrm{PPy} / \mathrm{AQS}$ and used $\mathrm{ACF} / \mathrm{PPy} / \mathrm{AQS}$ (triplicate use) were observed with SEM and the results were shown in Supporting information (SI) Fig. S4. The surface of both the ACF and ACF/ $\mathrm{PPy} / \mathrm{Na}_{2} \mathrm{SO}_{4}$ were smooth, while the surface of fresh ACF/PPy/AQS and used ACF/PPy/AQS had a uniform distribution of particles from electropolymerization with AQS.

The PPy molecule has nitrogen and $\mathrm{AQS}$ or $\mathrm{Na}_{2} \mathrm{SO}_{4}$ have sulfur, so the ratio of nitrogen and sulfur can represent the composition of $\mathrm{ACF} / \mathrm{PPy} / \mathrm{Na}_{2} \mathrm{SO}_{4}$ and $\mathrm{ACF} / \mathrm{PPy} / \mathrm{AQS}$. Results from elemental analysis indicated the presence of sulfur in each sample of $\mathrm{ACF} / \mathrm{PPy} / \mathrm{AQS}$ and $\mathrm{ACF} / \mathrm{PPy} / \mathrm{Na}_{2} \mathrm{SO}_{4}$. The mole ratios of AQS and PPy or $\mathrm{Na}_{2} \mathrm{SO}_{4}$ and PPy in the electropolymerized matrix were about 5:1.

The FTIR spectra of ACF, ACF/PPy/ $/ \mathrm{Na}_{2} \mathrm{SO}_{4}$ and ACF/PPy/AQS in the region from $4000 \mathrm{~cm}^{-1}$ to $400 \mathrm{~cm}^{-1}$ are shown in Fig. 1 . AQS was verified by the characteristic absorption band of highly conjugated $\mathrm{C}=\mathrm{O}$ groups, such as quinones and/or carbonyl groups near hydroxyl groups observed at $1678 \mathrm{~cm}^{-1}$ in the spectrum of ACF/ PPy/AQS (Li et al., 2008). The bands at $1580 \mathrm{~cm}^{-1}$ and $1457 \mathrm{~cm}^{-1}$ could be assigned to the $\mathrm{C}-\mathrm{N}$ stretching vibration in the Py ring (Omastová et al., 2004). The band at $1040 \mathrm{~cm}^{-1}$ was due to the symmetric stretching vibration of $\mathrm{S}=\mathrm{O}$ and has been observed in the spectrum for ACF/PPy/AQS (Tian and Zerbi, 1990). The bands located at $875 \mathrm{~cm}^{-1}$ and $710 \mathrm{~cm}^{-1}$ also corresponded to the stretching vibration of $S=0$, which was the characteristic absorption band of a sulfonic group. The weak bands observed at $1123 \mathrm{~cm}^{-1}$ and $635 \mathrm{~cm}^{-1}$ in the spectrum of ACF/PPy/AQS corresponded to the C-S bond (Li et al., 2008).

Raman spectral shifts and relative intensity changes in the 900$1200 \mathrm{~cm}^{-1}$ range showed a less drastic difference when comparing $\mathrm{ACF}$ and $\mathrm{ACF} / \mathrm{PPy} / \mathrm{Na}_{2} \mathrm{SO}_{4}$ (Fig. S5). But for ACF/PPy/AQS, the band at $1250 \mathrm{~cm}^{-1}$ was due to the symmetric stretching vibration of $\mathrm{C}=\mathrm{O}$ and the bands at $1065 \mathrm{~cm}^{-1}, 1092 \mathrm{~cm}^{-1}, 973 \mathrm{~cm}^{-1}$ and $937 \mathrm{~cm}^{-1}$ corresponded to the symmetric stretching vibration of $\mathrm{S}=\mathrm{O}$ for the sulfonic group of AQS (Sadowska et al., 2009). The band at $1330-1600 \mathrm{~cm}^{-1}$ was due to graphite (Sadowska et al., 2009).

The results of above analysis showed that this electropolymerization was an effective immobilization method for the dissolved redox mediator AQS.

\subsection{The effect of ACF/PPy/AQS on the denitrification efficiency}

The adsorption results for $\mathrm{ACF} / \mathrm{PPy} / \mathrm{Na}_{2} \mathrm{SO}_{4}$ and $\mathrm{ACF} / \mathrm{PPy} / \mathrm{AQS}$ without microorganisms served as the blank control for the effect of $A C F / P P y / A Q S$ on the denitrification experiments. The adsorption of $\mathrm{ACF} / \mathrm{PPy} / \mathrm{Na}_{2} \mathrm{SO}_{4}$ and $\mathrm{ACF} / \mathrm{PPy} / \mathrm{AQS}$ all caused little change (0.2\%) in the nitrate concentration (400 $\mathrm{mg} \mathrm{NO}_{3}^{-}-\mathrm{N} \mathrm{L}^{-1}$ ) over $48 \mathrm{~h}$. Therefore, the adsorption of nitrate by ACF/PPy/AQS could be neglected in the experiment in this study.

Fig. 2 showed the denitrification efficiency of ACF/PPy/AQS with different redox mediator concentrations and an initial nitrate concentration of $400 \mathrm{mg} \mathrm{NO}_{3}^{-}-\mathrm{N} \mathrm{L}^{-1}$. After $14 \mathrm{~h}$ of the denitrification reaction, the nitrate concentrations were $137 \mathrm{mg} \mathrm{NO}_{3}^{-}-\mathrm{N} \mathrm{L}^{-1}$, $102 \mathrm{mg} \mathrm{NO}_{3}^{-}-\mathrm{N} \mathrm{L}^{-1}, 72 \mathrm{mg} \mathrm{NO}_{3}^{-}-\mathrm{N} \mathrm{L}^{-1}$ and $37 \mathrm{mg} \mathrm{NO}_{3}^{-}-\mathrm{N} \mathrm{L}^{-1}$ at the AQS concentration of $0 \mathrm{mmol} \mathrm{L}^{-1}, 0.01 \mathrm{mmol} \mathrm{L}^{-1}, 0.02 \mathrm{mmol}$ $\mathrm{L}^{-1}$ and $0.04 \mathrm{mmol} \mathrm{L}^{-1}$, respectively. The denitrification efficiency was enhanced from $65.75 \%$ to $90.75 \%$ by ACF/PPy/AQS with $0.04 \mathrm{mmol} \mathrm{L}^{-1} \mathrm{AQS}$ (Fig. 2(a)). At the same time, the nitrite concentration first accumulated up to the highest concentration and was then converted into nitrous oxide, nitric oxide and nitrogen gas during the denitrification process. The denitrification steps were sequential and the product of one enzyme is a preceding step for the next one. Fine-tuned regulation of the concentration and activity of the denitrification enzymes was, therefore, required in order to keep the free concentrations of $\mathrm{NO}_{2}{ }^{-}$and $\mathrm{NO}$ below cytotoxic levels. The highest accumulated nitrite concentrations were $86 \mathrm{mg} \mathrm{L}^{-1}, 107 \mathrm{mg} \mathrm{L}^{-1}, 132 \mathrm{mg} \mathrm{L}^{-1}$ and $147 \mathrm{mg} \mathrm{L}^{-1}$ at the AQS concentration of $0 \mathrm{mmol} \mathrm{L}^{-1}, \quad 0.01 \mathrm{mmol} \mathrm{L}^{-1}, \quad 0.02 \mathrm{mmol} \mathrm{L}^{-1}$ and $0.04 \mathrm{mmol} \mathrm{L}^{-1}$, respectively (Fig. 2(b)). The reduction rate of nitrate to nitrite increased with AQS concentration, and the nitrite reduction rate was also enhanced by $\mathrm{AQS}$. $\mathrm{NO}_{2}^{-}$-reductase was induced in response to the high nitrite concentration after denitrification. The activity of $\mathrm{NO}_{2}^{-}$-reductase gave rise to an initial increase in the $\mathrm{NO}_{2}^{-}$-concentration. 

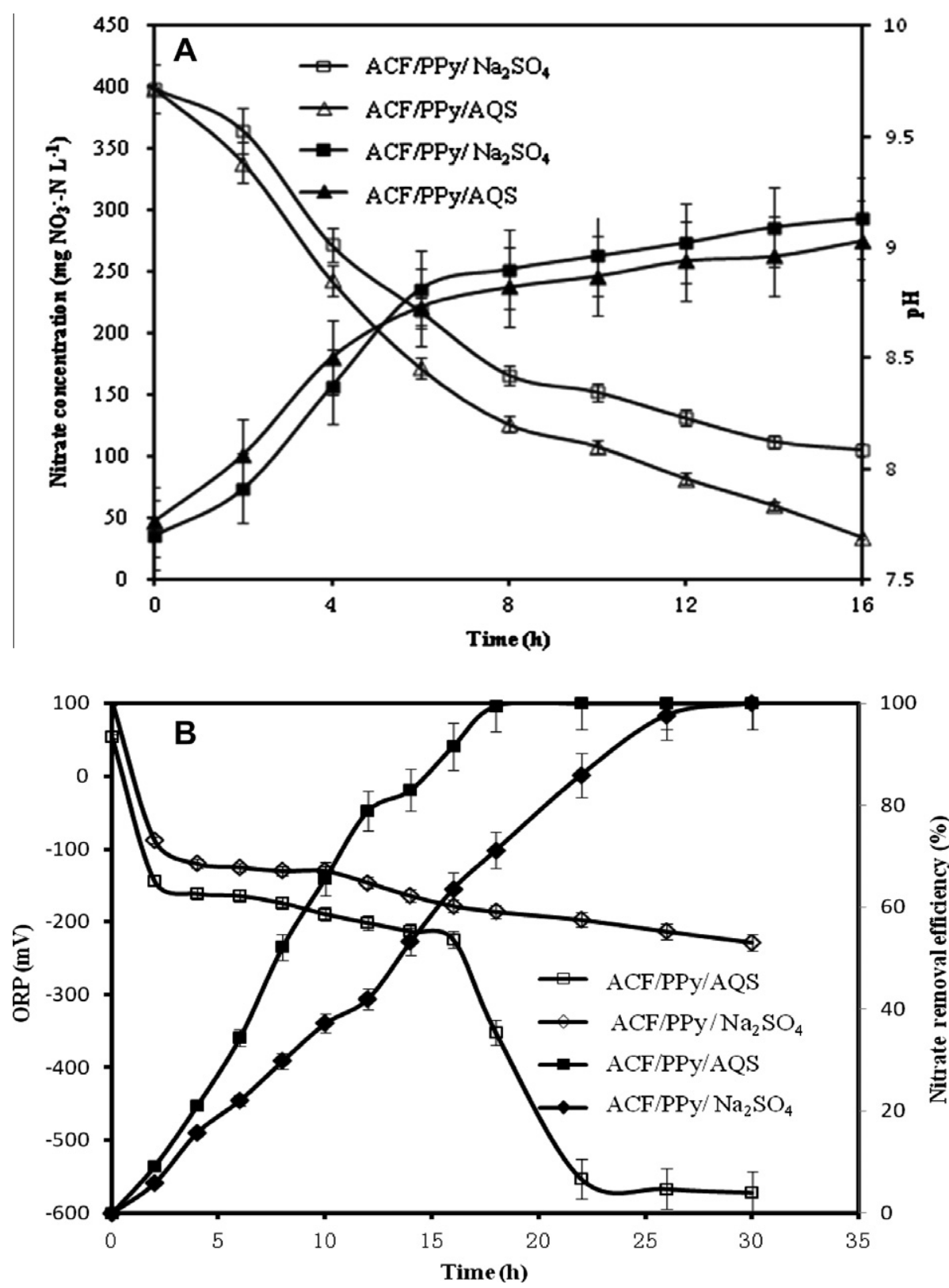

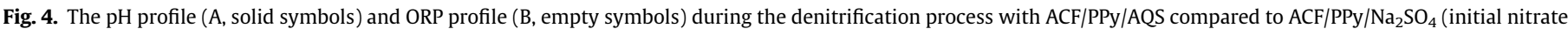
concentration: $400 \mathrm{mg} \mathrm{NO}_{3}-\mathrm{N} \mathrm{L}^{-1} ; 35^{\circ} \mathrm{C}$; initial $\mathrm{pH}$ : 7.0; $0.01 \mathrm{mmol} \mathrm{L}^{-1} \mathrm{AQS}$; carbon source: sodium acetate; C/N: 6; $5.7 \mathrm{~g}$ dry cell weight $\mathrm{L}^{-1}$ ).

The catalyzed denitrification process with $400 \mathrm{mg} \mathrm{NO}_{3}^{-}-\mathrm{N} \mathrm{L}^{-1}$ and $\mathrm{ACF} / \mathrm{PPy} / \mathrm{AQS}$ followed a modified pseudo-zero order model with $k=d C_{\text {Nitrate }} / d t$, where the reaction constant $k$ was computed by multiple regression analysis. The reaction constants $k$ $\left(\mathrm{mg} \mathrm{NO}_{3}^{-}-\mathrm{Ng}^{-1}\right.$ dry cell weight $\mathrm{d}^{-1}$ ) were 83.04, 90.24, 97.92 and 108 at corresponding AQS concentrations of $0 \mathrm{mmol} \mathrm{L}^{-1}$, $0.01 \mathrm{mmol} \mathrm{L}^{-1}, 0.02 \mathrm{mmol} \mathrm{L}^{-1}$ and $0.04 \mathrm{mmol} \mathrm{L}^{-1}$, respectively. A linear correlation was found for the $k$ value and the AQS concentration $\left(C_{\mathrm{AQS}}\right)$, which was $k=624.71 C_{\mathrm{AQS}}+83.87\left(R^{2}=0.9893\right)$. The accelerating effect of the redox mediator on the denitrification was similar to the decolorization rate of azo dye (Guo et al., 2007). The maximum removal rate was $108 \mathrm{mg} \mathrm{NO}_{3}^{-}$ $-\mathrm{N} \mathrm{g}^{-1}$ dry cell weight $\mathrm{d}^{-1}$, which is an attractive rate when compared with other denitrification processes (Table 1 ).

An initial nitrate concentration in the range of $200-700 \mathrm{mg} \mathrm{L}^{-1}$ was used to study the effect of nitrate concentration on the denitrification rate with the redox mediator. Fig. 3 shows that the denitrification rate was not significantly affected by the initial concentration in the tested range and followed a pseudo-zero order model, with an average denitrification rate of $78.96 \pm 18.96 \mathrm{mg} \mathrm{NO}_{3}^{-}-\mathrm{N} \mathrm{g}^{-1}$ dry cell weight $\mathrm{d}^{-1}$.

\subsection{The effect of ACF/PPy/AQS on the $\mathrm{pH}$ and ORP change during the denitrification process}

Fig. 4(a) shows that $\mathrm{pH}$ increased with nitrate removal for both denitrification processes with $A C F / P P y / A Q S$ and $A C F / P P y / N_{2} \mathrm{SO}_{4}$, but the $\mathrm{pH}$ value with $\mathrm{ACF} / \mathrm{PPy} / \mathrm{AQS}$ was lower than that with $\mathrm{ACF} / \mathrm{PPy} / \mathrm{Na}_{2} \mathrm{SO}_{4}$. This phenomenon might result from the different sources of the needed hydrogen proton for the denitrification process by the redox mediator and the biological denitrification process. For the biological denitrification process, the proton was supplied with the help of coenzymes, like NADPH/NADP ${ }^{+}, \mathrm{NADH} /$ $\mathrm{NAD}^{+}$and ubiquinol/ubiquinone $\left(\mathrm{Q} / \mathrm{QH}_{2}\right)$, while for the denitrification process with $\mathrm{ACF} / \mathrm{PPy} / \mathrm{AQS}$, the proton might come from the reduced redox mediator (Liu et al., 2011). 


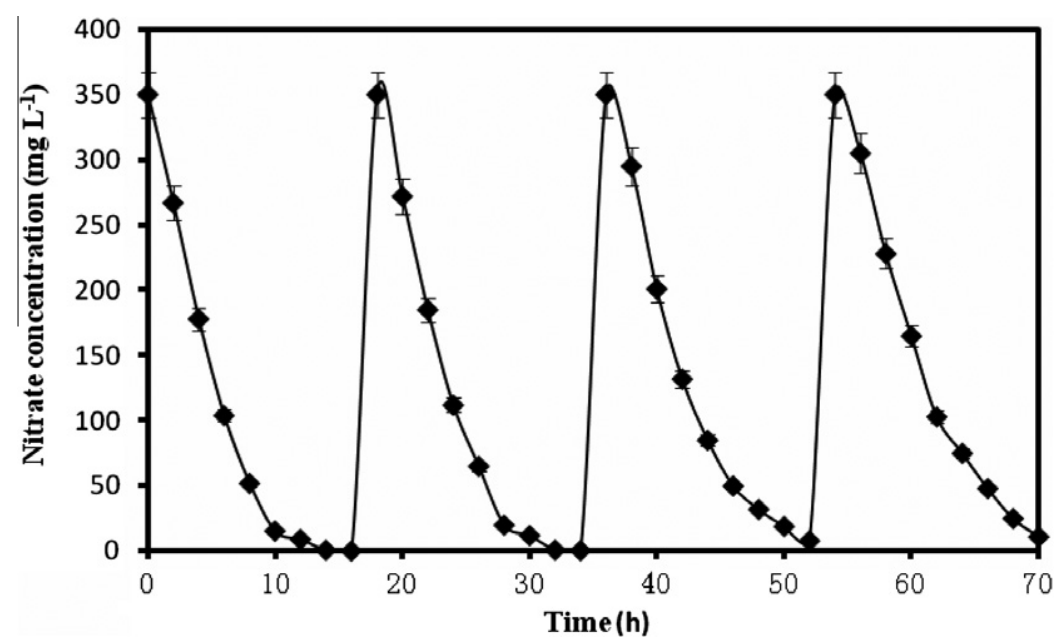

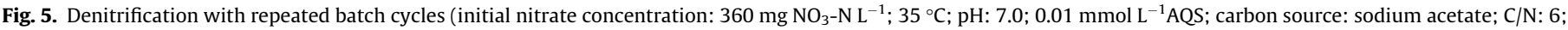
$5.7 \mathrm{~g}$ dry cell weight $\mathrm{L}^{-1}$ ).

The ORP was an important factor for the effective denitrification process, in which electrons are transferred from a reducing agent to an oxidizing agent until the reaction has reached equilibrium. In this experiment, the high denitrification efficiency with ACF/ PPy/AQS increased nearly 1.5 -fold in comparison to the control of $\mathrm{ACF} / \mathrm{PPy} / \mathrm{Na}_{2} \mathrm{SO}_{4}$. The ORP values stabilized around $-200 \mathrm{mV}$ for the denitrification process with ACF/PPy/AQS, which was similar to other results (Guo et al., 2007). The ORP stabilized values with $\mathrm{ACF} / \mathrm{PPy} / \mathrm{AQS}$ was $-25 \mathrm{mV}$ lower than the control (Fig. 4(b)). When nitrate was consumed completely, the ORP dropped to about $-580 \mathrm{mV}$. The different ORP between ACF/PPy/AQS and ACF/PPy/ $\mathrm{Na}_{2} \mathrm{SO}_{4}$ might mean that different primarily metabolic or bioreactions took place, namely the denitrification reaction and other bioreactions. The effect of the redox mediator on the ORP during denitrification is similar to the results reported for azo dye decolorization and denitrification processes with different a redox mediator (Guo et al., 2007, 2010).

Theoretically, according to the mechanism of traditional denitrification processes, the transformation of nitrate to nitrogen gas is an oxidation-reduction reaction, in which the transfer of electrons matches with proton flow with the help of coenzymes, like $\mathrm{NADPH} / \mathrm{NADP}^{+}, \mathrm{NADH} / \mathrm{NAD}^{+}$and ubiquinol/ubiquinone $(\mathrm{Q} /$ $\mathrm{QH}_{2}$ ). The ORP values of $\mathrm{NADPH} / \mathrm{NADP}^{+}, \mathrm{NADH} / \mathrm{NAD}+$ and $\mathrm{Q} /$ $\mathrm{QH}_{2}$ are $-324 \mathrm{mV},-320 \mathrm{mV}$, and $45 \mathrm{mV}$, respectively (Rau et al., 2002), and the ORP value of AQS is $-218 \mathrm{mV}$ (Kudlich et al., 1997), so the role of AQS may be similar to $\mathrm{Q} / \mathrm{QH}_{2}$. The catalyzing mechanism of the redox mediator in denitrification needs to be studied in detail using cell extracts and purified enzymes, which would allow a better understanding of the nature of the process.

\subsection{Repeated-batch operations}

After four cycles, the denitrification efficiency decreased less than $2 \%$ and the functional bio-carrier exhibited good reusability (Fig. 5). This also suggested that the redox mediator on the functional electropolymerization-biocarrier was recycled during the transfer of electrons from an electron donor to the terminal electron acceptor.

\section{Conclusion}

This study explored a new denitrification process with functional electropolymerization biocarriers of $\mathrm{ACF} / \mathrm{PPy} / \mathrm{AQS}$. The deni- trification efficiency with ACF/PPy/AQS (0.04 $\mathrm{mmol} \mathrm{L}^{-1}$ AQS) increased nearly 1.5 -fold compared to the control. A linear correlation of the $k$ value and the AQS concentration was $k=624.71 C_{\mathrm{AQS}}+83.87\left(R^{2}=0.9893\right)$ for an AQS concentration of $0-0.04 \mathrm{mmol} \mathrm{L}^{-1}$. The ORP value with ACF/PPy/AQS $\left(0.04 \mathrm{mmol} \mathrm{L}^{-1}\right.$ $\mathrm{AQS}$ ) was $-25 \mathrm{mV}$ lower than that with $\mathrm{ACF} / \mathrm{PPy} / \mathrm{Na}_{2} \mathrm{SO}_{4}$; AQS might play a similar role to that of cofactor ubiquinol/ubiquinone $\left(\mathrm{Q} / \mathrm{QH}_{2}\right)$ during the denitrification process. Repeated-batch operations exhibited good catalytic activity and durability after four repeated batch experiments.

\section{Acknowledgements}

This study was supported by the National Natural Science Foundation of China (Grant No. 50978082), the National High Technology Research and Development Program of China (Grant No. 2009AA06Z307), China Postdoctoral Science Foundation (Grant No. 20100480485) and the Program for New Century Excellent Talents in University (Grant No. NCET-10-0127).

\section{Appendix A. Supplementary data}

Supplementary data associated with this article can be found, in the online version, at doi:10.1016/j.biortech.2011.12.071.

\section{References}

Aranda-Tamaura, C., Estrada-Alvarado, M.I., Texier, A.C., Cuervo, F., Gomez, J., Bergendahl, J.A., Stevens, L., 2005. Effects of different quinoid redox mediators on the removal of sulfide and nitrate via denitrification. Chemosphere 69 (11), 1722-1727.

Bilanovic, D., Battistoni, P., Cecchi, F., Pavan, P., Mata-Alvarez, J., 1999. Denitrification under high nitrate concentration and alternating anoxic conditions. Water Res. 33 (15), 3311-3320.

Dhamole, P.B., Nair, R.R., D'Souza, S.F., Lele, S.S., 2007. Denitrification of high strength nitrate waste. Bioresour. Technol. 98 (2), 247-252.

Fernández-Nava, Y., Maránón, E., Soons, J., Castrillón, L., 2010. Denitrification of high nitrate concentration wastewater using alternative carbon sources. J. Hazard. Mater. 173 (1-3), 682-688.

Glass, C., Silverstein, J., 1999. Denitrification of high-nitrate, high-salinity wastewater. Water Res. 33 (1), 223-229.

Guo, J., Kang, L., Yang, J., Wang, X., Lian, J., Li, H., Guo, Y., Wang, Y., 2010. Study on a novel non-dissolved redox mediator catalyzing biological denitrification (RMBDN) technology. Bioresour. Technol. 101 (11), 4238-4241.

Guo, J., Zhou, J., Wang, D., Tian, C., Wang, P., Salah Uddina, M., Yu, H., 2007. Biocalalyst effects of immobilized anthraquinone on the anaerobic reduction of azo dyes by the salt-tolerant bacteria. Water Res. 41 (2), 426-432.

Hong, Y., Gu, J., 2009. Bacterial anaerobic respiration and electron transfer relevant to the biotransformation of pollutants. Int. Biodeterior. Biodegrad. 63 (8), 973980. 
Jetten, M.S., Wagner, M., Fuerst, J., van Loosdrecht, M., Kuenen, G., Strous, M., 2001. Microbiology and application of the anaerobic ammonium oxidation ('anammox') process. Curr. Opin. Biotechnol. 12 (3), 283-288.

Kudlich, M., Keck, A., Klein, J., 1997. Localization of the enzyme system involved in anaerobic reduction of azo yes by Sphingomonas sp. Strain BN6 and effect of artificial redox mediators on the rate of azo dye reduction. Appl. Environ. Microbiol. 63 (9), 3691-3694.

Li, L., Wang, J., Zhou, J., Yang, F., Jin, C., Qu, Y., Li, A., Zhang, L., 2008. Enhancement of nitroaromatic compounds anaerobic biotransformation using a novel immobilized redox mediator prepared by electropolymerization. Bioresour. Technol. 99 (15), 6908-6916.

Liu, H., Guo, J., Qu, J., Lian, J., Jefferson, W., Yang, J., Li, H., 2011. Catalyzing denitrification of Paracoccus versutus by immobilized 1,5dichloroanthraquinone. Biodegradation. doi:10.1007/s10532-011-9518-5.

Omastová, M., Trchová, M., Pionteck, J., ProkeS, J., Stejskal, J., 2004. Effect of polymerization conditions on the properties of polypyrrole prepared in the presence of sodium bis (2-ethylhexyl) sulfosuccinate. Synth. Met. 143 (2), 153161.

Pathak, B.K. Kazama, F. Saiki, Y. Sumino, T. 2007. Presence and activity of anammox and denitrification process in low ammonium-fed bioreactors. Bioresour. Technol. 98 (11), 2201-2206.

Rau, J., Knackmuss, H.J., Stolz, A., 2002. Effects of different quinoid redox mediators on the anaerobic reduction of azo dyes by bacteria. Environ. Sci. Technol. 36, 1497-1504.
Rodriguez, L., Villasenor, J., Fernández, F.J., 2007. Use of agro-food wastewater for theoptimisation of the denitrification process. Water Sci. Technol. 55 (10), 6370.

Sadowska, K., Roberts, K.P., Wiser, R., Biernat, J.F., Jabłonowska, E., Bilewicz, R., 2009. Synthesis, characterization, and electrochemical testing of carbon nanotubes derivatized with azobenzene and anthraquinone. Carbon 47 (6), 1501-1510.

Shen, J., He, R., Han, W., Sun, X., Li, J., Wang, L., 2009. Biological denitrification of high-nitrate wastewater in a modified anoxic/oxic-membrane bioreactor $(\mathrm{A} / \mathrm{O}$ MBR). J. Hazard. Mater. 172 (2-3), 595-600.

Suneethi, S., Joseph, Kurian, 2011. ANAMMOX process start up and stabilization with an anaerobic seed in Anaerobic Membrane Bioreactor (AnMBR). Bioresour. Technol. 102, 8860-8867.

Tian, B., Zerbi, G., 1990. Lattice dynamic and vibrational spectra of polypyrrole. J. Chem. Phys. 92 (6), 3886-3891.

Van der Zee, F.P., Cervantes, F.J., 2009. Impact and application of electron shuttles on the redox (bio) transformation of contaminants: a review. Biotechnol. Adv. 27 (3), 256-277.

Wang, J., Lu, H., Chen, J., Ngai Lau, J.G., Tsang, W.L., van Loosdrecht, M.C.M., 2009. A novel sulfate reduction, autotrophic denitrification, nitrification integrated (SANI) process for saline wastewater treatment. Water Res. 43 (9), 2363-2372.

Yang, X., Wang, S., Zhou, L., 2011. Effect of carbon source, C/N ratio, nitrate and dissolved oxygen concentration on nitrite and ammonium production from denitrification process by Pseudomonas stutzeri D6. Bioresour. Technol. doi:10.1016/j.biortech.2011.10.026. 